\title{
SELF-GOVERNMENT REFORMS AND PUBLIC SUPPORT FOR SPAIN'S TERRITORIAL MODEL: CHANGES AND STABILITY (1992-2010)
}

\section{Mireia Grau}

Responsible for Research, Institut d'Estudis Autonòmics

SUMMARY: I. Introduction. - 1. Self-Government Reforms: An Overview. - 2. Evolution of Preferences Regarding the Territorial Model: A Spain-wide Perspective. - 3. Evolution of Preferences Regarding the Territorial Model: A Perspective from the Autonomous Communities. - 3.1. Starting Point: the Pre-reform Period (1992-2002). 3.2. The First Steps in the Reforms: Period 2002-2005. - 3.3. The 2005-2010 Period and Conclusions. - II. References. - III. Appendices.

\section{Introduction}

The decentralised institutional scene in Spain has changed over the years. Since the autonomous communities were established in the early eighties, formal reforms and political settlements have defined the structure and functioning principles of self-government. Simultaneously, and according to opinion polls, throughout this period Spanish citizens have had a very positive attitude towards decentralisation and have progressively internalised the basic aspects of the system. As a result, in 1998 the level of support and commitment that citizens expressed for the country's decentralised structure reached similar levels to that expressed for democracy (Llera, 2002: 321-377; Mota, 2008: 87-110). In the light of these data, it seemed that positive feelings towards the system could be considered to be not only stable but also consolidated.

The author would like to thank Esther Martínez and Sandra Planes for their assistance in statistical matters; and also to two anonymous reviewers who suggested changes and ideas that have contributed to improve this piece of work. 
However, further developments have shown that this stability was not structural. In early 2000 a wave of institutional reforms of selfgovernment was carried out provoking intense social and political debate. Leaving aside the failed reform of the Basque Country's Statute of Autonomy (2004), much controversy was aroused in 2004 by the process that eventually led to the passing of the reform of Catalonia's Statute of Autonomy in 2006. Perceived by some as an illegitimate instrument designed to introduce major changes into the political structure of the whole country and, by others, as a legitimate tool to qualitatively improve and explicitly define the political nature of self-government, the fact is that the terms and nature of the reform of Catalonia's Statute were not just confined to Catalonia but also affected other autonomous communities. The Catalan reform gave fresh impetus to the political need to carry out reforms in other autonomous communities, which wholly or partially inspired the contents of these reforms, and fed a heated debate on the territorial issue at both political and social levels. Whether or not these reforms had a direct impact on public opinion, the fact is that simultaneously with the reforms, opinion polls revealed a number of changes in both the intensity and direction of long-term trends in the levels of support that citizens had hitherto given to the Spanish model of political decentralisation. In 2010, these changes were confirmed at both Spanish-wide and autonomous-community levels: support for further decentralisation contracted and support for centralism and for a milder decentralisation grew, although this picture differed across the different autonomous communities, showing three distinctive groups: the group of autonomous communities dissatisfied with the current model and aiming at moving further in the decentralisation process; the group of autonomous communities satisfied with the current model; and the group of autonomous communities in which support for a regression in the current model of decentralisation (moving towards a model in which the autonomous communities would have fewer powers or, even, a centralist model) has become the first preference or is showing an upward trend.

In general terms, the objective of this article is to contextualise changes in citizens' perceptions between 1992 and 2010 for each autonomous community and in the light of the wave of reforms initiated in 2003 and according to the evolution of the different autonomouscommunity patterns.

In order to do so, the article has been divided into four sections. The first section will describe the context of the reforms; the second will show the long-term trends of what can be regarded as citizens' political 
attitudes towards the territorial model of political decentralisation. This description will be based on the chronological evolution of opinion poll data relating to preferences for the territorial model and will provide a picture of Spain as a whole. The data have been taken from surveys carried out by the Centro de Investigaciones Sociológicas -CIS- (Centre of Sociological Research) from the early 1980 s to the present. Once the main trends and changes have been described, the third section will analyse these changes at autonomous-community level by seeking to identify different patterns of change. In other words, the main focus will be on identifying changes and whether or not they have followed similar patterns in the different autonomous communities.

\section{Self-Government Reforms: An Overview}

In 2004 the Basque Parliament approved a proposal to reform the Basque Country's Statute of Autonomy. The reform, spurred on by the then Basque nationalist premier, laid out a plan for a confederal relationship between the autonomous community and Spain. The proposal was, however, unsuccessful. Like any reform of a statute of autonomy, although formally initiated and proposed by the autonomous community's parliament, it had to be submitted to the Spanish Parliament for approval. The Basque proposal was firmly rejected at that initial stage of submission. However, from a political perspective, it constituted the first step towards a new phase of self-government reforms.

Self-government reforms had been carried out before 2004, but one of the main differences between the earlier reforms and the later ones concerns who promoted them. While reforms prior to 2004 had been promoted and largely controlled by the central government with the support of both the party in office and the main opposition (statewide parties), from 2004 the reforms clearly had their origins in the autonomous communities (Viver, 2010). Whether elite-initiated or enjoying a degree of social support, the fact is that the impetus for the new period of reforms originated at autonomous-community level was tolerated, though to a certain extent, by the central government and institutions.

Prior to 2004, however, self-government reforms had been related to the implementation and deployment of the political agreement reached between the central government and the opposition: the 1992 Agreement (Pactos Autonómicos). The then Socialist government agreed with the opposition party, the conservative People's Par-

188 ty (Partido Popular, PP), regarding the constitutional path to be fol- 
lowed by most of the autonomous communities in order to attain higher levels of powers. In other words, the agreement was designed to control the timing and the process by which the autonomous communities would acquire greater powers. It applied to the 13 autonomous communities that had been created after 1981 and which were required to follow the slow-track process of empowerment. Of course, although the process was largely controlled from the centre, each autonomous community had formally to initiate the reform of their respective statutes of autonomy in order to include the new powers. Between 1992 and 1999, therefore, these autonomous communities were encouraged to reform their statutes. In essence, this consisted in assuming new powers. As a result, at the end of the 1990s and as a result of these top-down reforms, the statutes of autonomy of all the autonomous communities formally reached similar levels of powers. ${ }^{1}$

Apart from these centrally-induced self-government reforms linked to the distribution of powers, two-fold significant reforms affecting the autonomous communities took place in 1993 and 1996: the reforms of the financing system of the autonomous communities that were addressed to increase the autonomous-community margin of fiscal accountability and, consequently, to reduce the large level of fiscal (and thus, political) dependence that the autonomous communities have on central government.

To the matters of this article, a crucial aspect characterises the reforms of the financing system and distinguishes them from the second wave of self-government reforms: the financing system was not understood as a self-government issue but as a state-wide issue and, therefore, although the reforms were formally spurred by the autonomous communities, the arenas in which negotiations took place were intergovernmental (within the multilateral intergovernmental forum on autonomous-community fiscal and financing committee Consejo de Política Fiscal y Financiera) and state-wide parliamentary, that is, within the Spanish Parliament (when reforms implied a legislative change, i.e. in 1996). ${ }^{2}$ To put it simpler, since its establishment

1. There are a large number of works dealing with this period. Among them Hernández and González, 1993. For an overview of the whole period, see Aja 1999.

2. Reforms of the financing system resulted from post-electoral agreements concluded by the Spanish Socialists in 1993, and by the People's Party in 1996 with the then party in office in Catalonia, Convergència i Unió (CiU). Beyond post-electoral events and negotiations, the point to be highlighted here is that although it was the party in office in the Catalan government, a Catalan nationalist party, that pushed the reform to the Spanish 
in the early 1980, the financing of the autonomous communities had been institutionally defined and settled as a state-wide and not a self-government issue. However, that the financing of the autonomous communities should also be defined and mainly understood from a self-government perspective, was one of the key issues of the second wave of reforms: the reforms promoted from the autonomous communities were addressed to reform, individually and according to their respective definition of problems and demands, the basic norms of self-government: the statutes of autonomy.

From a purely chronological perspective the first proposal of the second wave of institutional reforms was, as mentioned above, that of the Basque Country (2004). It was followed by those of Cata-

Table 1. Second Wave of Self-Government Reforms (2004-2010). Chronology

\begin{tabular}{|l|c|c|c|}
\hline & $\begin{array}{c}\text { Passing of the Proposal } \\
\text { for Reform (Autonomous } \\
\text { Community's Parliament) }\end{array}$ & $\begin{array}{c}\text { Passing of the Reform } \\
\text { (Spanish Lower } \\
\text { Chamber) }\end{array}$ & $\begin{array}{c}\text { Ratification } \\
\text { through } \\
\text { Referendum }\end{array}$ \\
\hline Basque Country & 30.12 .2004 & Rejected: $01.02 .2005^{1}$ & - \\
\hline Valencian Community & 01.07 .2005 & 09.02 .2006 & 18.06 .2006 \\
\hline Catalonia & 30.09 .2005 & 31.03 .2006 & 18.02 .2007 \\
\hline Andalusia & 02.05 .2006 & 02.11 .2006 & - \\
\hline Balearic Islands & 13.06 .2006 & 21.12 .2006 & - \\
\hline Aragon & 21.06 .2006 & 15.03 .2007 & - \\
\hline Canary Islands & 13.09 .2006 & Withdrawn ${ }^{2}$ & - \\
\hline Castile and León & 29.11 .2006 & 30.10 .2007 & - \\
\hline Castilla-La Mancha & 29.01 .2007 & Withdrawn & - \\
\hline Extremadura & 10.09 .2009 & In progress & - \\
\hline Navarre & 21.06 .2010 & 30.09 .2010 & - \\
\hline
\end{tabular}

Source: Compiled by the author from parliamentary proceedings.

1 The proposal was submitted to the Spanish Lower Chamber which rejected it by overall majority in February 2005.

2 In 2008, the Parliament of the Canary Islands formally asked to withdraw its proposal from the Spanish Parliament.

${ }^{3}$ In 2010, the Parliament of Castilla-La Mancha asked to withdraw its proposal from the Spanish Parliament.

governmental agenda, the reform of the financing system had been high on the agenda of the autonomous communities long before. In other words, the electoral results just opened a window of opportunity and the autonomous communities, led by the Catalan government, took advantage of it and brought about a state-wide change. See Monasterio et al. (1993); and Models and Puy (1996). 
Ionia and the Valencian Community (2005), Andalusia, the Balearic Islands, Aragon, the Canary Islands, Castile and León (2006), CastillaLa Mancha (2007), Extremadura (2008) and Navarre (2009), and two of them, those of the Canary Islands and Castilla-La Mancha were withdrawn by their respective autonomous parliaments (see Table 1).

As mentioned above, the crucial difference between these reforms and those carried out in the first wave is the fact that they were instigated at autonomous-community level, although there were fundamental differences with regard to the amount of social support they enjoyed. While some reforms had the support of the citizenry, others were promoted principally by their respective political elites, who took advantage of this window of opportunity but lacked both the explicit and implicit support and even the interest of their citizens. In this respect and in order to show the most extreme examples, in 2005, when asked whether it was necessary to reform the statute of autonomy, $65 \%$ of Catalan citizens thought this was

Figure 1. Perceptions of the Need to Reform the Statutes of Autonomy (\%) 2005

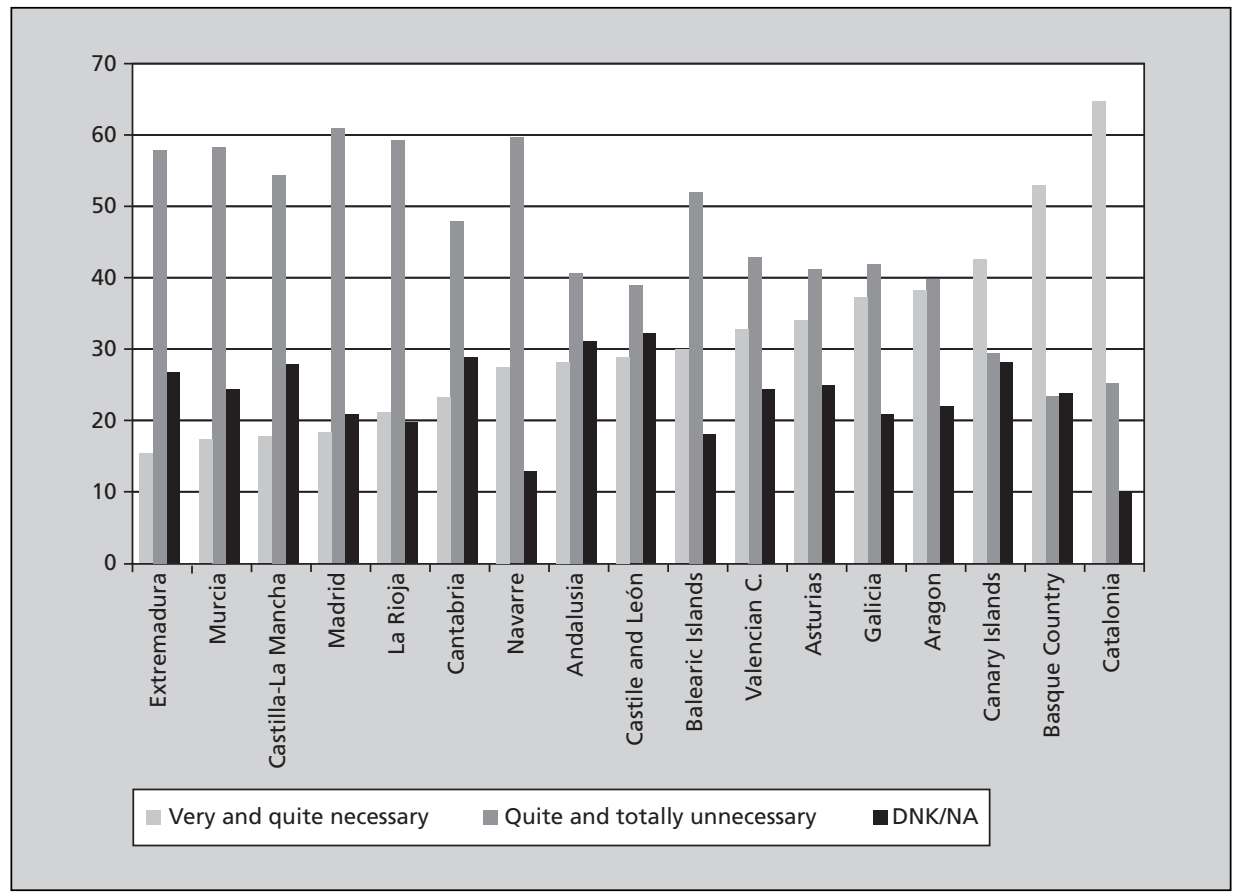

Source: Compiled by the author according to data from the CIS survey \#2610 (2005). 
necessary, while only $18 \%$ of the citizens of Castilla-La Mancha were of a similar opinion (see Figure 1 ). ${ }^{3}$

Leaving aside the Basque case because of the content of the reform - designed to establish a confederal relationship with Spain and the particular contextual and structural situation of the Basque Country in relation to central institutions ${ }^{4}$ it can be said that unlike the first wave of centrally-induced reforms, the acquisition of more powers by the autonomous communities was far from being the only issue. However, although some reforms were aimed mainly at enlarging and updating the contents of powers, the crucial and most controversial issue was related to another novel objective established and introduced by Catalonia's reform: the establishment of legal mechanisms designed to improve the quality of self-government. These mechanisms were basically designed to prevent central government from intruding into the exclusive powers of the autonomous communities, to establish the participation of Catalonia within statewide institutions, and to provide a degree of financial sufficiency; that is, the financing issue was included in the pack of the self-government reform. ${ }^{5}$ At stake, therefore, was the political meaning of self-government itself in relation to central institutions, and, above all, how this should be established legally.

Disagreements regarding the definition of the meaning of selfgovernment and the means used to legally establish such a definition were at the core of the heated and intensely political legal and social debate that arose immediately after the very first step was taken in that direction by the leading actors, the institutions of Catalan selfgovernment. Whether any reform, and especially a Catalan-type reform, should lead to a new phase in the development of decentralisation in Spain, and whether this was positive or negative were the main issues of the social debate. Simultaneously, opinion polls showed some changes in the long-established patterns of citizens' views of the system. Whether and to what extent reforms and their debates had a contextual impact upon citizens' views of the system is certainly a question that arises when one has a look at the evolution of citizens' views of the institutional system. I now turn to it.

3. Data from survey \# 2610 (CIS).

4. I refer here to issues relating to terrorism and fiscal independence.

5. See Viver i Pi-Sunyer forthcoming. For details on the process to reform Catalonia's statute in English, see Colino, 2009; and Keating and Wilson, 2009. 


\section{Evolution of Preferences Regarding the Territorial Model: A Spain-wide Perspective}

Over the last twenty years, the Centro de Investigaciones Sociológicas (CIS) has systematically carried out opinion polls regarding different aspects of the development of political decentralisation. Among other issues, the CIS surveys have attempted to provide evidence of citizens' support for the Spanish model of political decentralisation as a whole, on the perceptions of the impact of the different levels of government on their daily life, and on the attachment that citizens feel toward their respective autonomous governments. One of the questions that has been asked refers to citizens' preferences regarding the model of territorial organisation. This question has appeared in most Spain-wide surveys since the early 1980s, which means that figures for Spain as a whole are available dating back to this time. Representative samples at autonomous-community level were not systematically available before 1992. At that time, the CIS initiated a set of polls that have since been conducted simultaneously in all 17 autonomous communities; today these polls are known as the "autonomous-community barometer" (Barómetro Autonómico) and have been carried out on five occasions: in 1992, 1998, 2002, 2005 and $2010 .{ }^{6}$ Between 1992 and 2005 the question proposed four alternative models for organising political power: 1) a centralist political system; 2) a political system with autonomous communities "as they are"; 3) a system in which the autonomous communities would have higher levels of power; and 4) a system where the autonomous communities would become independent states. In 2010, in addition to these four alternative models, a fifth model was included in the questionnaire: a decentralised political system based upon autonomous communities, but with fewer powers than at present. As we will see, this new inclusion radically altered existing patterns, although at the same time it might also reveal some hitherto hidden or possibly newly-acquired aspects of citizens' views on political decentralisation. The analysis of the evolution of this question between 1992 and 2010 will form the basis of this section, firstly at a Spain-wide level and secondly at autonomous-community level.

6. Reference for 1992 surveys:\# to \#2025-2041; reference for 1998: 2286; reference for 2002: 2555; reference for 2005: 2610; reference for 2010: 2829. 
Figure 2. Evolution of Preferences Regarding the Model of Territorial Organisation (1984-2010) Spain-wide figures (\%)

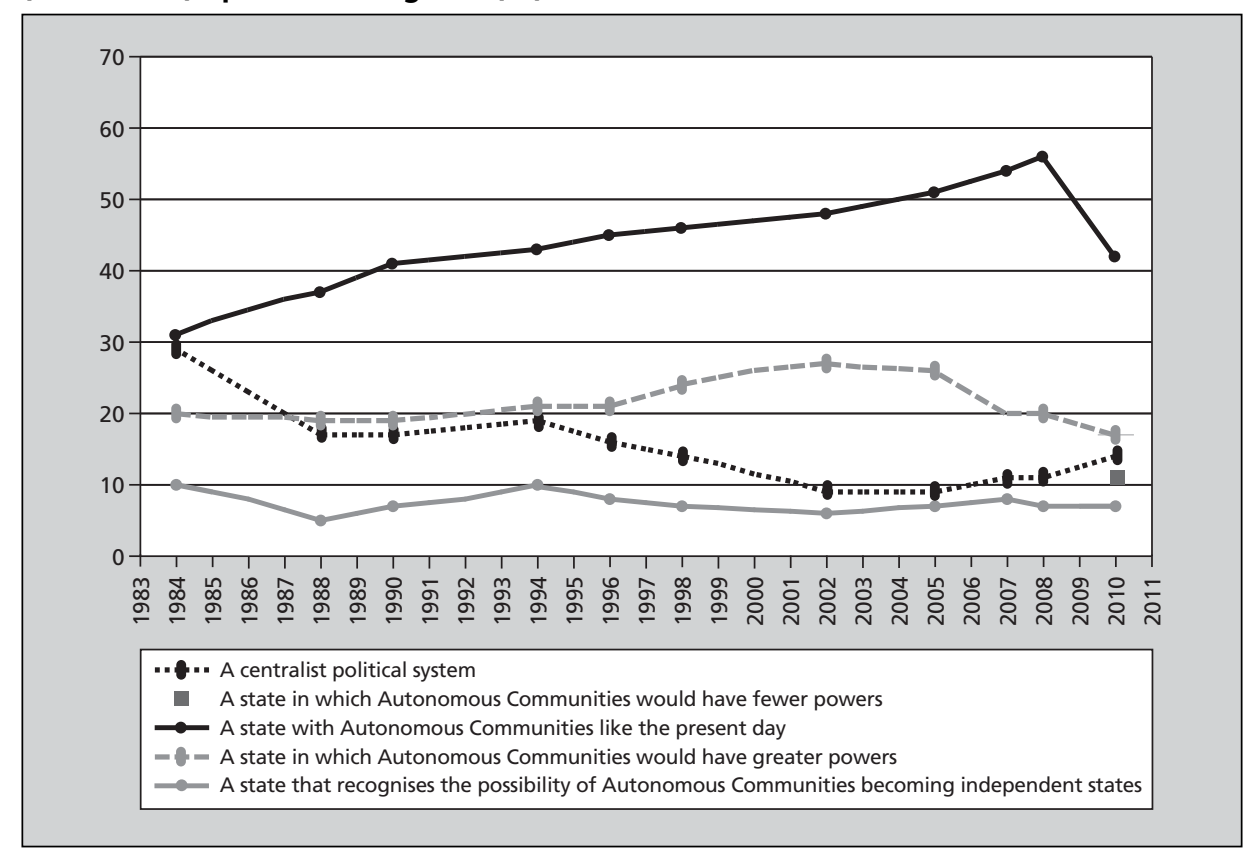

Source: Compiled by the author using data from the CIS.

Figure 2 shows the evolution of citizens' preferences regarding the model of territorial organisation of power between 1984 and 2010; it gives Spain-wide figures, that is, taking Spain as a whole. ${ }^{8}$ The most important trends are the following:

Although the starting point (1984) of citizens' preferences for a centralist system and for the then recently established system of autonomous communities were very similar (each receiving around $30 \%$ of citizens' support), the two options developed in opposite directions: support for a model like the current one with autonomous communities (status quo model) was the only preference that kept growing until 2008. In contrast, the option for a centralist system

7. Data for 1984 from survey \#1441; for 1988, survey \#1773; for 1990: \#1908; for 1994: \#2286; for 2002: \#2455; for 2005: \# 2619; for 2007: \# 2667; for 2008: \#2757; for 2010: 2829 .

8. When interpreting Figure 1, one should bear in mind that changes in 2010 are largely the result of the impact of the inclusion of a new fifth alternative model in the questionnaire. 
kept declining; in 2005 it reached its lowest level ever (8.7\%) and then initiated a notable recovery: $11.2 \%$ in 2007 and $14.1 \%$ in 2010. As for the minority secessionist option, this has remained relatively stable at around $7 \%$.

Between 2008 and 2010 support for the status quo option decreased dramatically, losing around $13 \%$ of popular support, from $55.5 \%$ to $42.4 \%$. The fundamental cause for this contraction is related to the transfer of support from the status quo to the new model included from 2010 in the questionnaire (fewer powers to the autonomous communities). However, two, probably intertwined, reasons may account for such a transfer: first of all, transfers can be related to a better accommodation of people's views in this new questionnaire. Thus, one could assume that part of the previous support for the status quo was rather a second-best option that sincere support; in this sense, it can be said that the introduction of the new model revealed a hidden trend: that of people's support for a milder model of decentralisation that was, nevertheless, different to pure centralism. Secondly, transfers can also be related to consequences of the political context on people's views. From this perspective one could assume that to some citizens that would have previously given their support to the status quo, reforms would have brought about a change in the system. Consequently, the new status quo would no longer reflect their preferences. In this respect, their preferences would probably be better accommodated in the option for a decentralised system where the autonomous communities had fewer powers. For others, the reforms would have brought into question the basic attitudes of political decentralisation and, as a consequence, may have changed their overall view of the system. What had hitherto been considered to be a positive aspect became a negative one. Thus, from this perspective, depending on how much reforms would had changed their perceptions and basic attitudes to the system, citizens would have transferred their preferences either to a milder version of decentralisation (autonomous communities, but with fewer powers) or to a radical change: the centralist option. This change in perceptions may be related to the rise in the latter option since 2007, before the introduction of the new model into the questionnaire.

Finally, the option for a political model based on the autonomous communities holding greater powers (status-quo-plus), displays an interesting evolution which seems to be the most highly influenced by the political mood. Let us try to explain it. 
As one can see, support for granting greater powers to the autonomous communities remained very stable between 1984 and 1996 at around $20 \%$ of the population. It is interesting to note that 1996 was the last time that the central government extended the powers of the autonomous communities (the last top-down reform) and when reforms of the financing system took place. Between 1996 and 2005 , the percentage of support for the status-quo-plus option increased significantly reaching almost $30 \%$, but in 2007 the level of support for this option decreased to the same levels as in the early 1990s. The fact that this variation happened simultaneously with the take-off of the reforms raises a relevant question: to what extent reforms had an impact upon Spanish public opinion.

As a matter of fact, Figure 2 shows that changes in the recent evolution of support are in all but one case (preference for status quo) previous to 2010; that is, data suggest that changes although related to the questionnaire, may also be linked to the political context. Thus, after all it could be said that including a new model in the questionnaire contributed to a better understanding of some already existing timid changes in trends. Looking only at Spain-wide figures, it seems that despite being questioned, the status quo is still the preferred option among Spaniards, and that the second most popular option, that of deepening the level of political decentralisation (status-quo-plus), received more support when it was just a political expectation; as soon as it became a reality its popularity diminished and did so before any change in the questionnaire. But did it decrease everywhere? To what extent do these Spainwide trends correspond to the different political expectations existing within the country? And, even more importantly, to what extent could the existence of different autonomous-community trends featuring the people's views of the system also be taken as factors that influenced the direction and intensity of the possible impacts that reforms had upon citizens' support of status quo? Although this article does not aim at testing such hypothesis, it does aim at showing that the changes in public opinion that accompanied the processes of self-government reform in each autonomous community seem to be quite consistent with the long-term patterns of people's support for both status quo and further decentralisation. In other words, to some extent data seem to suggest that from 2005, changes in each autonomous community followed a previous path. This is where the description turns from general perspectives to the 196 autonomous communities. 


\section{Evolution of Preferences Regarding the Territorial Model: A Perspective from the Autonomous Communities}

Since the aim here is to identify changes during and after the recent bottom-up reforms, it seems appropriate to divide the 1992-2010 period into three sub-periods: 1992-2002: the pre-reform period, 20022005: the initial period of reforms and 2005-2010: the period of development of the reforms. Although the 1992-2002 period might seem too long compared to the length of the other two, it is also true that the 1992-2002 period was above all a very stable period not just at the Spain-wide level but also for each autonomous community. The objective is, therefore, to explore for each period how different (or similar) the autonomous communities have been from the Spanish pattern, and to analyse these patterns for the whole length of time and, thus, contextualise changes. ${ }^{9}$

For each period a table will show the most significant reference points for each period: Spanish average means,$^{10}$ Spanish average rate of growth for each preference, the extreme values (maximum and minimum values) and the difference between these two. The two Spanish averages provide two different points of reference, that of the degree of support in relation to the Spain-wide model and that of the average direction of trends; the maximum and minimum values and their distance provide a simple picture of the extreme differences that exist between autonomous communities. These three tables, together with Table B (differentials for each autonomous community with respect to the Spanish averages) and $C$ (rates of growth for each autonomous community) of the Appendices are the elements used here to group the autonomous communities and identify patterns of change and stability in the temporal evolution of the support for territorial organisation in autonomous communities.

\footnotetext{
9. The analysis of the evolution of preferences regarding the territorial model in all the autonomous communities will be based on two parameters: the differences in average means with respect to Spain-wide ones for three different periods of analysis (19922002; 2002-2005 and 2005-2010), and the rates of growth for each preference in each of the above-mentioned periods (see Tables $A$ and $B$ in the Appendix). The analysis of the different means is designed to depict the autonomous communities in relation to Spain as a whole and to identify patterns of evolution over the three periods. The rates of growth will indicate the direction of changes within each autonomous community.
}

10. Table 2, Table 3 and Table 4. Sources of these tables: Tables A, B and C in the Appendices. 


\subsection{Starting Point: the Pre-reform Period (1992-2002)}

Table 2. Main Features of the 1992-2002 Period

\begin{tabular}{|l|c|c|c|c|c|}
\hline & $\begin{array}{c}\text { Spanish } \\
\text { average (\%) }\end{array}$ & $\begin{array}{c}\text { Maximum } \\
\text { Average }\end{array}$ & $\begin{array}{c}\text { Minimum } \\
\text { Average }\end{array}$ & $\begin{array}{c}\text { Differential } \\
\text { max-min }\end{array}$ & $\begin{array}{c}\text { Average } \\
\text { Rates of } \\
\text { Growth }\end{array}$ \\
\hline Centralism & 12.3 & $\begin{array}{c}21.7 \\
\text { (Murcia) }\end{array}$ & $\begin{array}{c}3.7 \\
\text { (Basque Country) }\end{array}$ & 18 & $-32.58 \%$ \\
\hline Status Quo & 44.4 & $\begin{array}{c}53.1 \\
\text { (Valencian C.) }\end{array}$ & $\begin{array}{c}29.9 \\
\text { (Aragon) }\end{array}$ & 23.2 & 22.25 \\
\hline Status Quo Plus & 24.1 & $\begin{array}{c}32.9 \\
\text { (Aragon) }\end{array}$ & $\begin{array}{c}15.3 \\
\text { (Murcia) }\end{array}$ & 27.6 & 21.39 \\
\hline Secessionism & 6.5 & $\begin{array}{c}19.5 \\
\text { (Basque Country) }\end{array}$ & $\begin{array}{c}0.9 \\
\text { (Asturias) }\end{array}$ & 18.6 & -6.5 \\
\hline No answer & 12 & $\begin{array}{c}23.3 \\
\text { (Asturias) }\end{array}$ & $\begin{array}{c}6.6 \\
\text { (Valencian C.) }\end{array}$ & 15.7 & -39.5 \\
\hline
\end{tabular}

Table 2 shows the main features of the 1992-2002 period, a long period characterised by two main trends (see Figure 2): the constant growth and consolidation of the status quo option at very high levels of support, the stability and slight increase in support for status-quoplus, and the relatively constant decrease in support for centralism. On average, though, centralism displayed a downward trend. Support for the status quo displayed an upward trend, at a rate of $22 \%$. Status-quo-plus includes almost a quarter of the population and displays a positive rate of growth (+21.4). The average support for secession $(6.5 \%)$ conceals the high levels of the Basque Country $(19 \%)$ and of the other two autonomous communities that chose this option. For the rest, the scoring was generally insignificant.

Regarding the distribution of each autonomous community, ${ }_{1}^{11}$ two main groups can be distinguished for the 1992-2002 period: 1) autonomous communities where the status quo is not the first preference and which aim at increasing their level of self-government; 2 ) autonomous communities satisfied with the status quo and mostly in favour of no changes in any direction.

The first group included the autonomous communities that registered low average levels of support for the status quo and high levels of support for deepening decentralisation. In short, they are au- 
tonomous communities that preferred further extension of the decentralisation process. It included the Basque Country, Catalonia, the Canary Islands, the Balearic Islands and Aragon. It must be highlighted that all of them initiated, in the 2002-2005 period, a process to reform their respective statutes of autonomy.

Within this group, the Basque Country and Catalonia stand out as the most coherent patterns: apart from displaying the lowest levels of support for the status quo and displaying a trend towards the decrease of this option, they also reject any backward steps in decentralisation (low levels of centralism and regression) and display the highest scores in support of deepening decentralisation (upward trend) and secession. The other autonomous communities do not display the same degree of coherence and their characteristics need some explanation: the Canary and Balearic Islands both score very high in status-quo-plus and their support for centralism is certainly lower than the Spanish average; the differences between them are related to the intensity of the support for the status quo (much lower in the Balearic Islands) and in the direction of support for statusquo-minus and secession: while the Balearic Islands display a slightly higher degree of support for secession with respect to the Spanish average, the Canary Islands show a slightly lower level of support. Aragon is a rather unusual case: apparently its scores in some preferences (one of the weakest supporters for the status quo option and one of the strongest supporters for status-quo-plus) do not appear to match its very high levels of support for centralism. Such apparent incoherence may have something to do with a two-fold dissatisfaction with the status quo: on the one hand, dissatisfaction because of its limitations with respect to self-government, and on the other, dissatisfaction because the status quo is perceived to go too far. In other words, Aragon's apparently incoherent scoring may be related to a quite divided society with regard to preferences for the model of territorial decentralisation: Aragonese people were dissatisfied with the status quo but for two rather different reasons and aiming at two different objectives.

The second group included two types of autonomous communities: the autonomous communities that were highly satisfied with the "status quo" but relatively open to changes designed to increase levels of self-government (Castile and León, Asturias, Galicia, Andalusia, Cantabria, Extremadura, Castilla-La Mancha and the Valencian Community), and the autonomous communities (Murcia, Madrid and La Rioja) that despite being satisfied with the status quo were slight- 
ly less in favour of changes in the direction of self-government since they went in the opposite direction to the average Spanish trend: they displayed negative rates of increase for status-quo-plus.

Navarre is a case that does not fit into any group. It scores high in the status quo (support for which continues to grow), registers a medium-high level in status-quo-plus (a downward trend), displays low levels of centralism (which continues to decrease) and scores high in secession. In other words, Navarre's scores and trends show that its society is divided into two sectors: the sector of citizens that are fully satisfied with the status quo (which, it must be said, is characterised by a somewhat greater degree of self-government than that of the other autonomous communities with the exception of the Basque Country) and the sector that radically rejects the model and supports secession.

\subsection{The First Steps in the Reforms: Period 2002-2005}

Table 3. Main Features of the 2002-2005 Period

\begin{tabular}{|l|c|c|c|c|c|}
\hline & $\begin{array}{c}\text { Spanish } \\
\text { average (\%) }\end{array}$ & $\begin{array}{c}\text { Maximum } \\
\text { Average }\end{array}$ & $\begin{array}{c}\text { Minimum } \\
\text { Average }\end{array}$ & $\begin{array}{c}\text { Differential } \\
\text { max-min }\end{array}$ & $\begin{array}{c}\text { Average } \\
\text { Rates of } \\
\text { Growth }\end{array}$ \\
\hline Centralism & 8.7 & $\begin{array}{c}17.6 \\
\text { (Aragon) }\end{array}$ & $\begin{array}{c}2.3 \\
\text { (Basque Country) }\end{array}$ & 15.3 & -5.43 \\
\hline Status Quo & 51.4 & $\begin{array}{c}74.5 \\
\text { (Extremadura) }\end{array}$ & $\begin{array}{c}23.5 \\
\text { (Catalonia) }\end{array}$ & 51 & +6.86 \\
\hline Status Quo Plus & 26.3 & $\begin{array}{c}48 \\
\text { (Catalonia) }\end{array}$ & $\begin{array}{c}11.5 \\
\text { (Extremadura) }\end{array}$ & 56.5 & -0.75 \\
\hline Secessionism & 6.6 & $\begin{array}{c}29.2 \\
\text { (Basque Country) }\end{array}$ & $\begin{array}{c}0.2 \\
\text { (Castile and León) }\end{array}$ & 29 & +4.76 \\
\hline No answer & 7.1 & $\begin{array}{c}11.6 \\
\text { (Andalusia) }\end{array}$ & $\begin{array}{c}2.9 \\
\text { (Extremadura) }\end{array}$ & 8.7 & -2.9 \\
\hline
\end{tabular}

This period is the one during which self-government reforms started. With respect to the previous period, the 2002-2005 period was, at the Spain-wide level, a period of apparent consolidation of the status quo as the most popular option: support reached $51.4 \%$ and continued to grow. Thus, in a way, it seems that there was a strengthening of the conviction that it was the "best" option. However, it is also true that the distance between extreme figures increased dramatically: while in the previous period the distance was 
23 percentage points (between 53.1 and 29.9), in this period the distance doubled to 51 points, with Extremadura as the most enthusiastic supporter of the status quo ( $74.5 \%$ of citizens) and Catalonia the least enthusiastic (23.5\%), both extremes represent an increase with respect to the previous period. Therefore, as Figure 1 showed for Spain as a whole, data for 2002-2005 period suggest that the autonomous communities chose to move in opposite directions: towards the strengthening of the status quo (the majority) and towards its weakening (the minority). Similarly, status-quo-plus, despite scoring slightly higher than in the previous period, showed signs of recession: its rates of growth were negative. In other words, changes occurred and in two opposite directions: in some autonomous communities support for status-quo-plus decreased while in others it increased dramatically. Another indicator of changes during the period is the increasing popularity of secession, above all because secession is an option that is concentrated in three autonomous communities (Basque Country, Catalonia and Navarre); in other words, preference for secession grew so significantly in these autonomous communities that it was enough to compensate for the stable and even negative rates of growth registered in the remaining autonomous communities.

Accordingly, two groups can be distinguished and although they basically embrace the same autonomous communities and features that composed and depicted the two groups in the previous period, they differ in the intensity of their respective trends: a growing negative attitude towards the status-quo (as for the group of autonomous communities dissatisfied with the status-quo) and the strengthening of the status-quo and a growing negative attitude towards any change implying further decentralisation (as for the group of autonomous communities satisfied with the status-quo). The first group included Catalonia, Basque Country, Aragon ${ }^{12}$ and the Balearic Islands; the second one included the remaining fourteen, of course, showing internal differences basically rooted in the levels of support and positive taxes of growth for centralism: the Canary Islands, Asturias, Extremadura, Castile and León, Cantabria and Galicia showed no

\footnotetext{
12. As in the previous period, Aragon showed its apparently contradictory features due to its double root of dissatisfaction with the status quo, although as a difference, dissatisfaction rooted in frustrated demands of self-government seemed to have reached its peak and give signs of recession with negative rates of growth for status quo plus, as mentioned before.
} 
significant trends towards centralism while Castilla-La Mancha, Andalusia, Madrid and Murcia did show them. ${ }^{13}$

To sum up, it seems quite clear that a number of changes took place during the 2002-2005 period. In the majority of autonomous communities these changes affected support for the status quo (which increased dramatically) and for status-quo-plus (which decreased). In this respect, it could be said that self-government reforms, apart from not being perceived as necessary by citizens, may have strengthened citizens' attachment to the status quo and the rejection of furthering the development of self-government. Support for centralism grew but not radically and not everywhere.

In Catalonia, the Basque Country, the Balearic Islands and Aragon, changes in territorial preferences showed a radically different trend and referred to status quo. In Catalonia, the Basque Country and the Balearic Islands, dissatisfaction with the status quo dropped to early-1980s levels and in the Catalan case support for status-quoplus became the majority option, showing the expectations Catalans had regarding the reform of their statute. In Aragon, the data seem to indicate that the numbers of those who were dissatisfied with the status quo due to its limitations with regard to self-government tended to diminish (negative rates of growth for status-quo-plus), which could be interpreted as satisfaction with the steps taken to reform the Aragon statute of autonomy.

\subsection{The 2005-2010 Period and Conclusions}

Table 4. Main Features of the 2005-2010 Period

\begin{tabular}{|l|c|c|c|c|c|}
\hline & $\begin{array}{c}\text { Spanish } \\
\text { average (\%) }\end{array}$ & $\begin{array}{c}\text { Maximum } \\
\text { Average }\end{array}$ & $\begin{array}{c}\text { Minimum } \\
\text { Average }\end{array}$ & $\begin{array}{c}\text { Differential } \\
\text { max-min }\end{array}$ & $\begin{array}{c}\text { Average } \\
\text { Rates of } \\
\text { growth }\end{array}$ \\
\hline Centralism & 14.1 & $\begin{array}{c}1.8 \\
\text { (Aragon) }\end{array}$ & $\begin{array}{c}24.8 \\
\text { (Basque Country) }\end{array}$ & 23 & 62.07 \\
\hline Status Quo Minus & 11.2 & Asturias (18.5) & Navarre (4.3) & 14.2 & - \\
\hline Status Quo & 42.4 & $\begin{array}{c}56.1 \\
\text { (Murcia) }\end{array}$ & $\begin{array}{c}26.3 \\
\text { (Catalonia) }\end{array}$ & 29.8 & -17.51 \\
\hline
\end{tabular}

13. Although it must be taken into account that positive rates of growth in centralism do not reflect the differences in the departing points: in Andalusia support for centralism was far below the Spanish average, so any increase impacted heavily on its rates of growth. 


\begin{tabular}{|l|c|c|c|c|c|}
\hline Status Quo Plus & 16.6 & $\begin{array}{c}29.7 \\
\text { (Balearic Islands) }\end{array}$ & $\begin{array}{c}6.6 \\
\text { (Madrid) }\end{array}$ & 23.1 & -36.88 \\
\hline Secessionism & 6.5 & $\begin{array}{c}23.6 \\
\text { (Catalonia) }\end{array}$ & $\begin{array}{c}0.3 \\
\text { (Aragon) }\end{array}$ & 23.3 & -1.52 \\
\hline No answer & 9.3 & $\begin{array}{c}12.5 \\
\text { (Cantabria) }\end{array}$ & $\begin{array}{c}4.9 \\
\text { (Canary Islands) }\end{array}$ & 7.6 & 30.99 \\
\hline
\end{tabular}

During this period most of the processes to reform the statutes were completed. In 2006, four reforms were passed, those of the Valencian, Catalan, Andalusian and Balearic Islands statutes. In summer 2006 Catalonia's Statute of Autonomy was finally passed by the Spanish Parliament and ratified by the Catalans through referendum. The resulting statute did not satisfy either those who had put great expectations in it as an instrument to move forward in the process of decentralisation or those who thought that the reform was going too far and wished to change the nature of the whole institutional system. Dissatisfaction due to the limited nature of the statute of autonomy was shown in the low levels of turnout in its referendum: only $48.85 \%$ of people on the electoral roll voted. As a result, in Catalonia secessionist options increased dramatically, support for status-quo-plus clearly diminished and centralist preferences returned to the levels of the 1980s. Dissatisfaction with the perceived dangers of the statute was mainly shown in the Spain-wide media and politics and, above all, in the reaction of conservative forces: the Spain-wide opposition party, the Partido Popular, challenged the constitutionality of Catalonia's statute in the Constitutional Court. In the other autonomous communities, the effects of the Catalan statute were, in some cases, accompanied by their own processes of self-government reform: Aragon, the Canary Islands, Castile and León, Castilla-La Mancha, Extremadura and Navarre. In the Canary Islands, disagreements between the two major Spain-wide parties over electoral aspects of the proposal to reform the Canary Islands' statute brought about the complete failure of the reform process and its abandonment; yet it should be remembered that in the Canary Islands support for the reform reached $42.5 \%$ of the population in 2005 (much higher than the average), thus implying the existence of a certain level of frustration among citizens.

Table 4 illustrates the turmoil surrounding self-government. First of all, the table includes the new territorial organisation option introduced by the CIS, that of a status quo system characterised by a reduction in the powers of the autonomous communities, what I call "status-quo-minus". In itself, the introduction of this new option reveals 
the change of perception regarding the developments the system has undergone and the need to understand them, especially with respect to changes in the status quo. Thus, secondly, the table shows that support for the status quo dropped by almost $10 \%$, mostly, probably, as a result of the transfers to status-quo-minus. Thirdly, support for status-quo-plus diminishes significantly and even more striking is the closing of the gap between extremes within this option: while in the 2002-2005 period this gap was more than 56 points, in this period it decreased to 23.1 points. There might be two reasons for this fall: in some autonomous communities it may be related to the rejection of self-government reforms due to their perceived negative effects on the system as a whole, and in some others it may be based on frustration and disappointment with the unfulfilled hopes for reform. In this sense, it must be pointed out that while in the 2002-2005 period Catalonia was displaying very high levels of support for status-quo-plus $(48 \%)$, in this period support dropped to $29.3 \%$.

Figure 3. Support for Territorial Options (\%). 2010

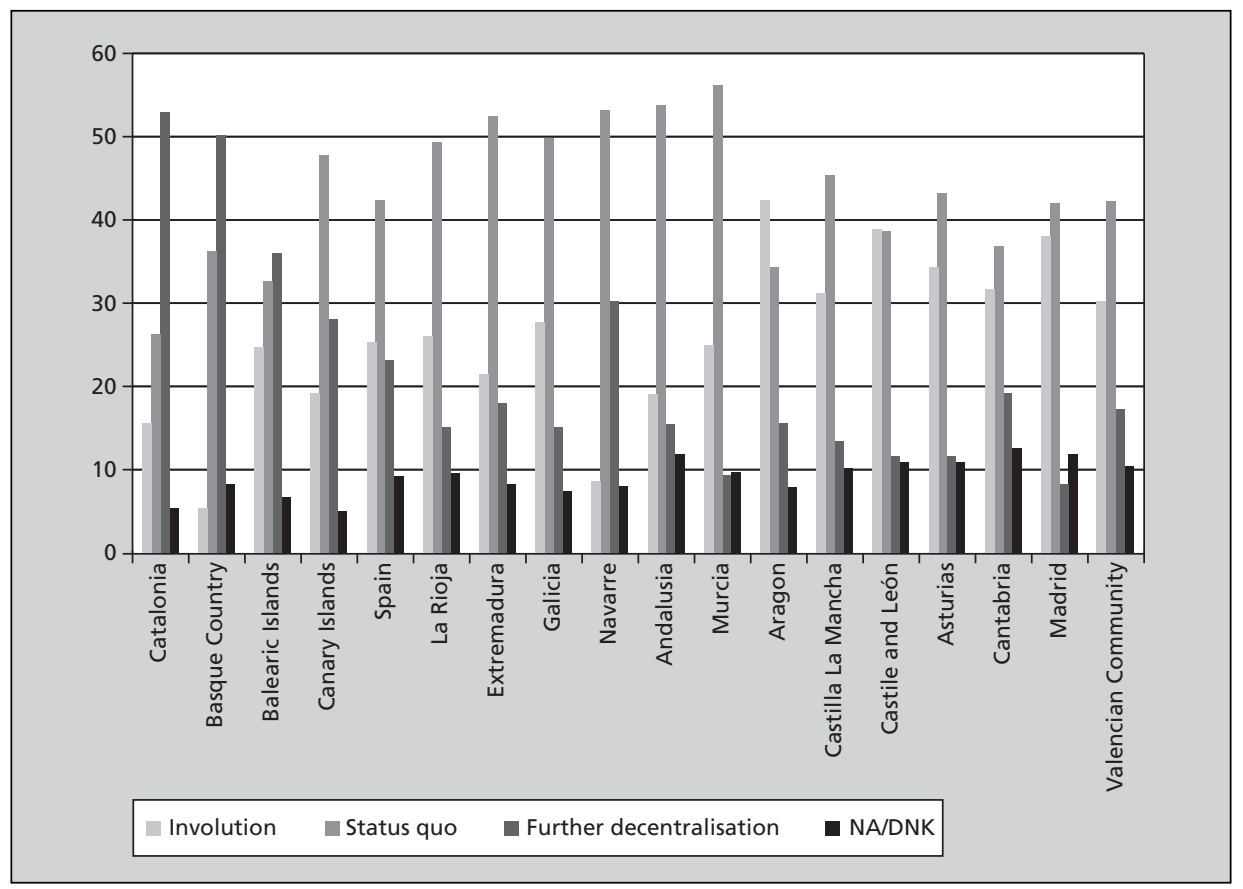

Source: Compiled by the author from CIS survey 2829. Involution includes the addition of centralist and status-quo-minus support (in \%); Status-quo represents support for this option only; further decentralisation includes the addition of support for status-quoplus and secession. 
In such a context, Figure 3 allows three groups of autonomous communities to be distinguished: first of all, the group of autonomous communities in which "further decentralisation" is the most preferred option implying, thus a dissatisfaction towards status quo (Catalonia, Basque Country and to a certain extent, the Balearic Islands); secondly the group of autonomous communities composed of those autonomous communities where, in spite of everything, support for the status quo option remained high, although lower than in the previous period. That is, this is the pro-status quo group: the $\mathrm{Ca}$ nary Islands, La Rioja, Galicia, Extremadura, Navarre, Andalusia and Murcia. Four of them initiated a process of self-government reform (the Canary Islands, Extremadura, Andalusia and Navarre). What they have in common is the predominance of support for the status quo displayed in the distribution of support, and their differences result above all from the respective weight of support for regression and less significantly from their support for further decentralisation.

A third group is composed of these autonomous communities that seem to be questioning the status quo and considering backward steps in the decentralisation system as a possible alternative: Aragon, Cantabria, Castile and León, Madrid, the Valencian Community, Asturias and Castilla-La Mancha. These autonomous communities have in common their low scores in status quo (in all but two cases below the Spanish average), their rejection of further decentralisation as well as a tendency to favour a regression in the decentralisation process as an alternative to the status quo: they all score high in both centralism and status-quo-minus and, even more significantly, for the first time in 30 years, options for regression score either higher than the status quo (Aragon and Castilla y León) or are very close to it. All of them display negative rates of growth for the status quo and status-quoplus options and positive ones for centralism. Surprisingly, this group includes four autonomous communities that carried out their own processes to reform their statutes of autonomy (Aragon, Castile and León, the Valencian Community and Castilla-La Mancha), which leads one to think that these reforms were not only elite-generated but had no social support at all, rather social rejection.

These three groups are quite coherent with statistically-significant results coming from Figure 4. Figure 4 shows how far apart citizens' perceived level of decentralisation (measured in a 0-10 scale in which 0 is maximum centralism and 10 is maximum decentralisation) is from citizens' expectations of how much centralised-decentralised the system should be. Accordingly, values around 0 show satisfaction with the cur- 
rent level of decentralisation (accommodation between perceived and wished level); positive values refer to claims for further decentralisation, and negative values refer to centralist attitudes. Figure 4 also shows the Spanish average mean and median. In this sense, it is interesting to note that firstly both the Spanish's average mean and median score negatively, and, secondly, that in all but four autonomous communities (the Basque Country, Catalonia, Navarre and the Balearic Islands), citizens' satisfaction towards the perceived level of decentralisation is negative. Thus, both aspects point out that with the exception of citizens from the four above-mentioned autonomous communities, citizens' perceptions of the degree of decentralisation are negative since they would rather prefer a less decentralised system.

Figure 4. Satisfaction with the perceived level of self-government. 2010

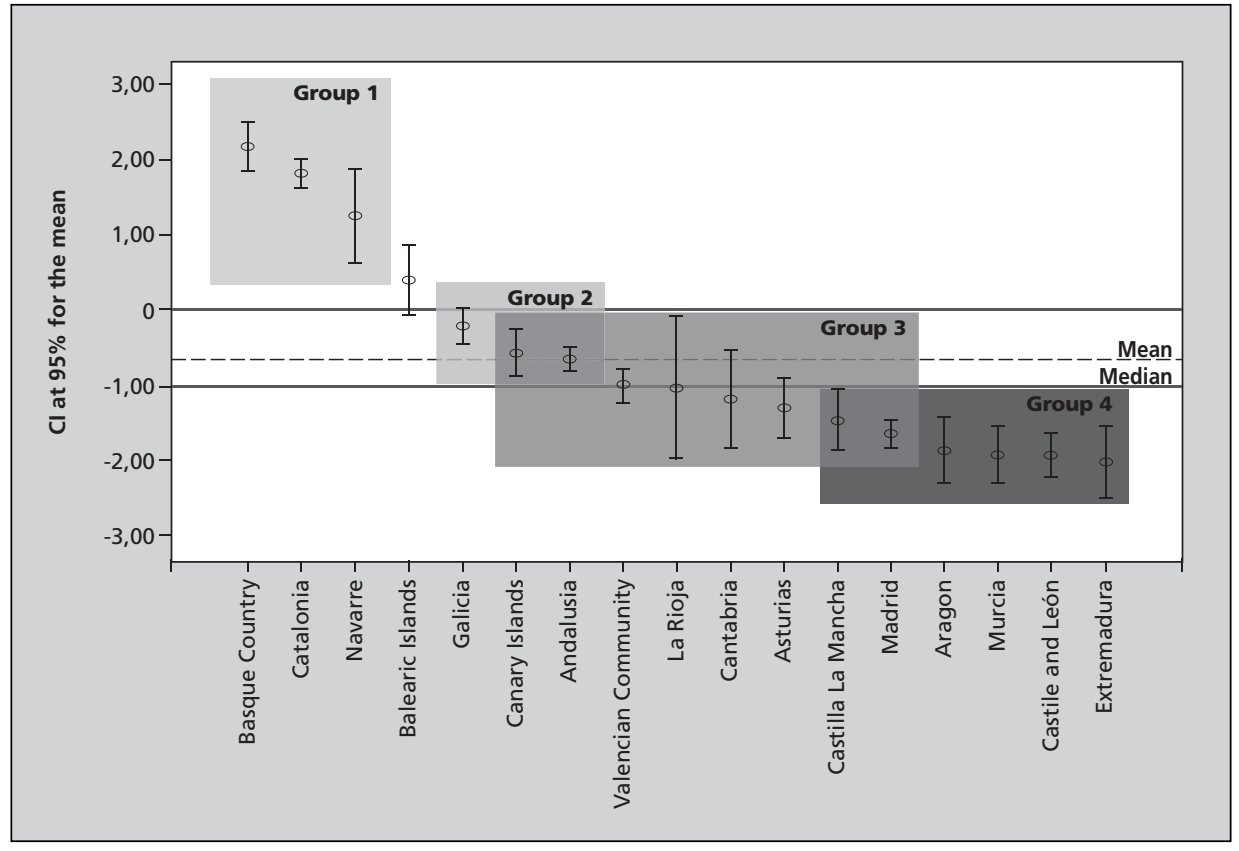

Source: Compiled by the author according to data from CIS survey 2829.14

14. Figure 3 results from the difference between means of questions 45 and 46 of the CIS poll \#2829. Question 45: A political system can be territorially organised in several ways. Given a set of values from 0 representing "highest centralism" and 10 representing "highest decentralisation" (considering even the self-determination of its territories), which value would you think corresponds to the existing Autonomous-Community system?; Question 46: And, which value would you like it to be? The figure shows confidence in- 
From Figure 4 four statistically-significant groups can be distinguished: Group 1 is composed of three autonomous communities whose citizens' preferences on how decentralised the system should be do not match with their perceptions on how decentralised the system is. In other words, they think the levels of self-government are insufficient. This group is composed of the Basque Country, Catalonia and Navarre. Group 2 is composed of autonomous communities whose averages are close to and a little higher than Spain's statewide average mean. Citizens from these autonomous communities would prefer a rather less decentralised system but, even though, they are satisfied with the current system. The group embraces Galicia, Canary Islands and Andalusia. Group 3, the largest group, is composed of autonomous communities whose averages are close to but below Spain's average mean and median. Citizens from these autonomous communities accept the current system despite their preference for a less decentralised and, therefore, a more centralist system (Valencian Community, La Rioja, Cantabria and Asturias). Finally, Group 4 is composed of autonomous communities whose citizens perceive that the current system is more decentralised than what they would like it to be (their average means are lower than Spain's average mean). Therefore, they show a rather clear preference for a less decentralised political system in which the autonomous communities would lose powers. The autonomous communities that are part of this group are Madrid, Aragon, Murcia, Castile and León and Extremadura. With the exception of Madrid and Murcia, the other three autonomous communities initiated their respective processes of self-government reform. In this sense and again, it could be said that the self-government reforms carried out in these autonomous communities had little social support and, thus, were rather promoted by their respective political elites as a political reaction regarding other processes of reform.

To sum up, between 1992 and 2010, self-government reforms have been accompanied by changes in citizens' preferences and support for the territorial organisation model. In the majority of cases these changes have merely accentuated existing trends, whether they were trends towards a regression in the decentralisation model or

tervals at $95 \%$ for the differential mean of each Autonomous Community. $95 \%$ of confidence entails a 95 out of 100 of certitude that the true value of the mean is located between the two extremes of the bar. Therefore, overlapping error bars do not entail statistically significant differences. 
towards further development of the decentralisation process and, as a consequence, have mostly affected support for the status quo option which, in general, has fallen dramatically. Thus, an interesting conclusion is that since self-government reforms took place, citizens' attachment to the status quo has changed. Two very different reasons may account for such a change: because the status quo may be perceived as a completely outdated model for those aiming at further decentralisation, and because the status quo, since it has allowed further development of the decentralisation process, may be perceived as the seed of unwanted change and, thus, involution is preferred. In short: simultaneously with the beginning of the bottom-up process to reform the statutes of autonomy, the status quo option seems to have been questioned, for different reasons, in several autonomous communities. In some of them, such questioning is not new: it is related to their unsatisfied aims for further decentralisation and their frustration with the current system and reforms. Reforms might have accelerated trends. In some others, such questioning is quite a novelty and could be related to the opposite situation: the status quo no longer seems to be the most popular base for the political system and involution has clearly appeared for the first time since the system was established. However, and assuming that such simultaneous events imply a relationship between reforms and changes in support for the status quo, they do not always seem to have resulted in the questioning of the system. Thus, in some autonomous communities citizens' positive perceptions towards the status quo do not seem to have changed significantly, at least in terms of perceptions. In other words and in spite of all the political turmoil generated by the reforms, citizens from some autonomous communities kept their loyalty towards the status quo although, in general, without being particularly in favour of further decentralisation changes. In any case the political scenario reveals a complex situation which is difficult to resolve unless asymmetries are not only allowed but also, and even more importantly, political elites understand that the copycat behaviour which has characterised the Spanish decentralisation process must end.

\section{References}

AJA, Eliseo. El Estado Autonómico. Federalismo y hechos diferenciales. Madrid: Alianza Editorial. 2003, 2nd ed. 
Couno, César. "Constitutional Change Without Constitutional Reform: Spanish Federalism and the Revision of Catalonia's Statute of Autonomy". Publius (2009) 39(2).

Hernández, Adolfo, and González, M. A. "Los Acuerdos Autonómicos de 28 de febrero de 1992: negociación, contenido y desarrollo". In Documentación Administrativa. 1993, no. 232-233: 135-184. 262-288.

Keating, Michael and WiLson, Alex. "Renegotiating the State of Autonomies: Statute Reform and Multi-level Politics in Spain". West European Politics. 2009, 32(3): 536-558.

LleRA Ramo, Francisco José. La opinión pública: la diversidad de una nación plural". In Subirats, Joan and Gallego, Raquel (eds) Veinte años de autonomías en España. Leyes, políticas públicas, instituciones y opinión pública, Madrid: Centro de Investigaciones Sociológicas, 2002.

Monasterio Escudero, Carlos and al. "Informe sobre el actual sistema de financiación y sus problemas". Report commissioned by the Fiscal and Financial Policy Council following the 1/1993 Agreement. Spanish Official Gazette (BOE) \# 188. Madrid: Instituto de Estudios Fiscales, 1995.

Mota Consejero, Fabiola. Capital social y gobernabilidad. El rendimiento político de las Comunidades Autónomas. Madrid: Centro de Estudios Constitucionales, 2008.

Moldes, Eduardo and Puy, Pedro. La Financiación de las Comunidades Autónomas. Madrid: Minerva Ediciones, 1996.

VIVER, Carles (forthcoming) "The Federal Constitution and Statutes of Autonomy: Explaining the Evolution of Political Decentralisation". In TARR, Alan and Burguess, Michael (eds.) Constitutional Dynamics In Federal systems: Sub-National Perspectives, Montreal: McGill-Queen's University Press. 


\section{Appendices}

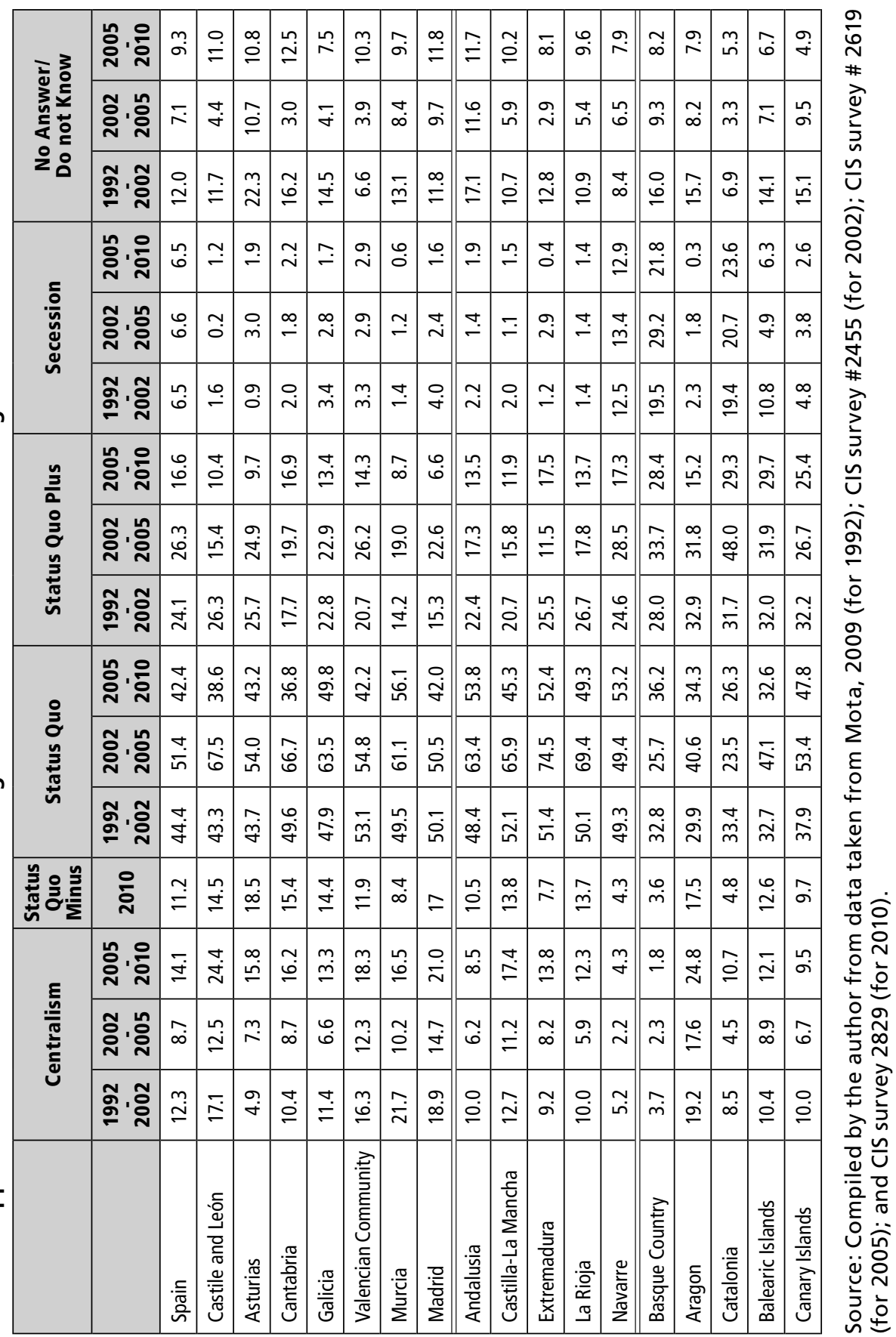




\begin{tabular}{|c|c|c|c|c|c|c|c|c|c|c|c|c|c|c|c|c|c|c|c|c|}
\hline \multirow{3}{*}{ 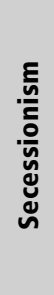 } & \multirow{2}{*}{ 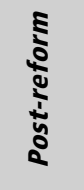 } & 눙융 & นִ & $\begin{array}{l}n \\
\varphi \\
\varphi\end{array}$ & $\mid \begin{array}{c}m \\
\stackrel{n}{i}\end{array}$ & $\underset{i}{\stackrel{\sim}{+}}$ & $\stackrel{m}{\underset{\gamma}{r}}$ & $\stackrel{\text { भे }}{+}$ & $\begin{array}{l}0 \\
\dot{P} \\
1\end{array}$ & 우 & 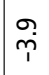 & $\underset{i}{\mathscr{+}}$ & $\bar{\varphi}$ & †े & $\stackrel{\infty}{\stackrel{i}{i}}$ & कृ & гं & $\mid \begin{array}{c}m \\
\stackrel{n}{n}\end{array}$ & $\overline{\check{\Sigma}}$ & ָ̃ \\
\hline & & 유. '. & $\begin{array}{l}\mathscr{0} \\
\ddot{0}\end{array}$ & $\begin{array}{l}\infty \\
\stackrel{+}{+}\end{array}$ & 它 & $\begin{array}{l}0 \\
\dot{r}\end{array}$ & $\stackrel{\infty}{\underset{\sim}{+}}$ & $\underset{i}{\stackrel{\sim}{\sim}}$ & $\hat{r}$ & \begin{tabular}{l|}
$\stackrel{\llcorner}{\sim}$ \\
$\stackrel{\varphi}{i}$
\end{tabular} & $\stackrel{\infty}{i}$ & นִ & $\hat{p}$ & $\begin{array}{l}\infty \\
\dot{0}\end{array}$ & $\begin{array}{c}\infty \\
\dot{p} \\
i\end{array}$ & 華 & นٌ & $\mid \stackrel{\circ}{\underset{\mathbf{N}}{*}}$ & $\overline{\dot{I}}$ & T. \\
\hline & ذِ & รั'ธิ & $\bar{\sigma}$ & $\underset{P}{\stackrel{Y}{Y}}$ & 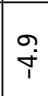 & $\begin{array}{l}0 \\
\dot{1} \\
\hat{1}\end{array}$ & 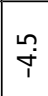 & $\stackrel{\sim}{\sim}$ & $\tilde{r}$ & 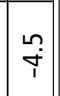 & $\frac{T}{T}$ & $\stackrel{m}{\underset{f}{m}}$ & $\stackrel{m}{\stackrel{m}{p}}$ & $\stackrel{0}{0}$ & $\bar{p}$ & iri & ir & $\mid \begin{array}{l}\stackrel{\dot{m}}{m} \\
\ddot{m}\end{array}$ & $\stackrel{\mathscr{I}}{\beth}$ & $\stackrel{m}{\sigma}$ \\
\hline छे & $\frac{2}{9}$ & 윰윰 & $\begin{array}{l}\mathscr{\varphi} \\
\underline{\varphi}\end{array}$ & $\frac{⿱ 亠 䒑}{T}$ & ְ̋ & $\begin{array}{l}9 \\
0 \\
1\end{array}$ & ma & 웅 & $\underset{i}{i}$ & $\stackrel{\vec{f}}{\mathrm{i}}$ & $\begin{array}{l}\infty \\
\infty \\
\infty\end{array}$ & $\bar{r}$ & $\stackrel{0}{0}$ & $\hat{o}$ & $\underset{n}{\tilde{r}}$ & $\stackrel{9}{T}$ & $\stackrel{\mathscr{T}}{T}$ & $\| \stackrel{\infty}{=}$ & 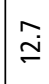 & $\bar{m}$ \\
\hline$\frac{\pi}{\vec{z}}$ & $\frac{\hbar}{2}$ & 오ํ' & 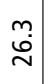 & เก & 高 & $\frac{1}{\pi}$ & ب) & $\hat{r}$ & $\bar{i}$ & \begin{tabular}{|l|}
$\stackrel{n}{0}$ \\
$\stackrel{0}{1}$
\end{tabular} & 它 & 우 & $\begin{array}{l}\infty \\
\stackrel{+}{\leftarrow}\end{array}$ & $\stackrel{\sim}{\sim}$ & $\dot{\vec{p}}$ & $\stackrel{m}{i}$ & $\begin{array}{c}n \\
0 \\
0 \\
1\end{array}$ & 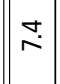 & $\hat{\bar{i}}$ & ம) \\
\hline பัँ & ذ่ & รั'ธิ & $\bar{d}$ & \begin{tabular}{l|}
$\infty$ \\
$\infty$ \\
$\infty$
\end{tabular} & $\tilde{N}$ & $\stackrel{n}{\sim}$ & \begin{tabular}{|l}
$n$ \\
0 \\
0 \\
1
\end{tabular} & \begin{tabular}{|c|c}
$\infty$ \\
$\infty$ \\
$\infty$ \\
1
\end{tabular} & $\stackrel{\vec{r}}{r}$ & 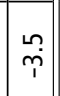 & $\bar{\infty}$ & $\frac{T}{T}$ & $\stackrel{m}{-}$ & $\stackrel{\circ}{\circ}$ & $\frac{m}{T}$ & \%̊ & $\stackrel{0}{\sim}$ & $\mid \stackrel{g}{m}$ & $\stackrel{\circ}{\stackrel{0}{*}}$ & 옥 \\
\hline 흥 & $\frac{0}{9}$ & 율융 & 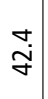 & $\underset{\infty}{\infty}$ & $\stackrel{\infty}{\stackrel{p}{r}}$ & $\stackrel{\infty}{\infty}$ & $\begin{array}{l}\varphi \\
\dot{\varphi}\end{array}$ & ț & Õ & $\stackrel{\leftrightarrow}{\sim}$ & in & $\stackrel{\nabla}{=}$ & $\stackrel{\circ}{\circ}$ & $\begin{array}{l}\infty \\
\stackrel{0}{\circ}\end{array}$ & $\stackrel{\sim}{\sim}$ & $\hat{m}$ & פ̧ & $\mid \begin{array}{l}\tilde{1} \\
\hat{\varphi}\end{array}$ & $\frac{\overline{6}}{1}$ & के \\
\hline 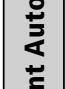 & $\frac{1}{2}$ & 오ํ' & $\stackrel{+}{\dot{n}}$ & $\begin{array}{l}\infty \\
\dot{0} \\
1\end{array}$ & $\bar{\sigma}$ & $\stackrel{o}{\sim}$ & $\begin{array}{l}m \\
\stackrel{m}{n}\end{array}$ & ợ & $\stackrel{\nabla}{m}$ & $\begin{array}{l}\stackrel{\sim}{\sim} \\
\dot{J}\end{array}$ & $\stackrel{\circ}{i}$ & $\stackrel{\circ}{\stackrel{i}{1}}$ & $\overline{\ddot{\sim}}$ & $\stackrel{0}{i}$ & $\bar{i}$ & ă & $\begin{array}{l}\circ \\
\infty \\
\infty\end{array}$ & $\underset{\sim}{\stackrel{\sim}{\sim}}$ & $\underset{T}{\stackrel{T}{T}}$ & $\stackrel{m}{r}$ \\
\hline 竞 & ذِ & 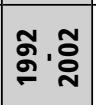 & $\stackrel{\nabla}{\dot{J}}$ & $\stackrel{n}{+}$ & $\frac{T}{T}$ & 审 & $\stackrel{N}{\sim}$ & in & $\hat{\infty}$ & $\stackrel{2}{\pi}$ & $\begin{array}{l}n \\
0 \\
0 \\
1\end{array}$ & $\stackrel{\leftrightarrow}{+}$ & $\stackrel{\circ}{\circ}$ & $\stackrel{\overbrace{}}{+}$ & $\stackrel{\sim}{m}$ & $\overline{\text { in }}$ & $\hat{\text { ni }}$ & 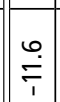 & $\frac{O}{\bar{T}}$ & $\stackrel{7}{\overline{1}}$ \\
\hline હે & $\frac{2}{5}$ & 늉유 웅 & $\stackrel{\sim}{=}$ & m̧ & $\stackrel{m}{m}$ & $\stackrel{m}{r}$ & $\stackrel{\sim}{\sim}$ & $\begin{array}{l}\infty \\
\text { ம் }\end{array}$ & ó & $\stackrel{0}{i}$ & $\frac{n}{T}$ & î́ & $\stackrel{n}{m}$ & $\begin{array}{l}0 \\
\text { } \\
\end{array}$ & $\stackrel{\sim}{m}$ & $\stackrel{\infty}{i}$ & $\stackrel{\sim}{\sim}$ & $\mid \begin{array}{l}0 \\
T\end{array}$ & 它 & 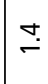 \\
\hline 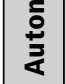 & $\stackrel{\overleftarrow{\Delta}}{\vdots}$ & 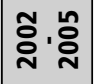 & & $\stackrel{\circ}{\circ}$ & $\because$ & $\because$ & $\because$ & $\stackrel{\circ}{0}$ & $\stackrel{0}{\circ}$ & $\because$ & $\because 0$ & 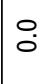 & $\because$ & $\stackrel{0}{\circ}$ & : & $\because$ & 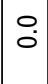 & $\mid \begin{array}{l}0 \\
0\end{array}$ & 웅 & $\stackrel{\circ}{\circ}$ \\
\hline$\dot{\Xi}$ & 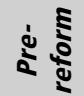 & รั. ัญ & & 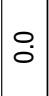 & $\because$ & $\because$ & $\because$ & O. & $\stackrel{\circ}{\circ}$ & $\circ$ & $\because$ & $\because$ & $\because$ & $\because$ & ㅇ. & ㅇ. & 0 & $\because$ & O & ㅇ. \\
\hline & $\frac{1}{5}$ & 늉융 & $\check{\Phi}$ & $\hat{0}$ & $\stackrel{m}{0}$ & $\cong$ & $\bar{i}$ & ğ & $\stackrel{\sim}{\sim}$ & $\begin{array}{c}m \\
m\end{array}$ & $\begin{array}{l}0 \\
+ \\
i\end{array}$ & 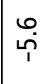 & 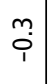 & $\begin{array}{l}\infty \\
\stackrel{1}{i} \\
\end{array}$ & $\begin{array}{l}\infty \\
0 \\
i\end{array}$ & $\stackrel{ナ}{\sim}$ & $\frac{\infty}{T}$ & $\underset{1}{\stackrel{m}{\sim}}$ & $\stackrel{\vec{r}}{\dot{r}}$ & $\stackrel{\stackrel{O}{i}}{i}$ \\
\hline 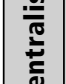 & 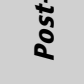 & 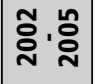 & $\widehat{\infty}$ & 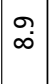 & $\begin{array}{l}\infty \\
m\end{array}$ & $\stackrel{\overbrace{}}{\leftarrow}$ & Oי & O̊ & $\stackrel{6}{\dot{m}}$ & $\stackrel{\sim}{\sim}$ & $\stackrel{0}{i}$ & $\stackrel{\sim}{i}$ & $\begin{array}{l}n \\
0 \\
i\end{array}$ & \begin{tabular}{|l}
$n$ \\
0 \\
$i$ \\
1
\end{tabular} & $\bar{i}$ & $\stackrel{2}{\sim}$ & $\stackrel{\infty}{i}$ & $\mid \begin{array}{l}\vec{f} \\
\dot{\varphi}\end{array}$ & $\underset{\sim}{\sim}$ & ชี \\
\hline & ذ่ & รั' ัญ & $\stackrel{m}{\stackrel{m}{\sim}}$ & જூ & $\stackrel{\infty}{\stackrel{\sim}{*}}$ & 芳 & $\frac{9}{1}$ & 它 & $\check{f}$ & $\stackrel{\text { Ln }}{0}$ & $\stackrel{m}{i}$ & $\stackrel{m}{i}$ & $\bar{p}$ & $\stackrel{\circ}{i}$ & $\begin{array}{l}0 \\
0 \\
1\end{array}$ & นn & $\stackrel{m}{i}$ & $\mid \begin{array}{l}n \\
\infty \\
\infty \\
1\end{array}$ & $\hat{m}$ & $\frac{\mathscr{T}}{1}$ \\
\hline & & & 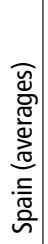 & 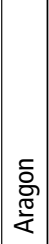 & 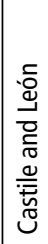 & 桭 & 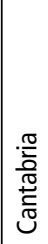 & $\begin{array}{l}\frac{\overline{0}}{\frac{0}{2}} \\
\frac{\pi}{2}\end{array}$ & 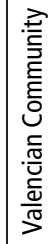 & 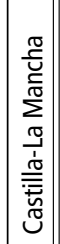 & 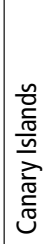 & 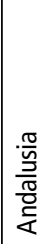 & 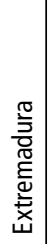 & $\begin{array}{l}\frac{0}{2} \\
\frac{0}{0} \\
\frac{0}{2}\end{array}$ & 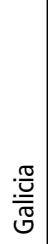 & $\frac{\pi}{\frac{\pi}{2}}$ & $\begin{array}{l}\frac{\pi}{2} \\
\frac{\pi}{2} \\
\frac{\pi}{3}\end{array}$ & 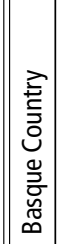 & 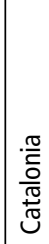 & 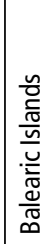 \\
\hline
\end{tabular}




\begin{tabular}{|c|c|c|c|c|c|c|c|c|c|c|c|c|c|c|c|c|c|c|c|}
\hline \multirow{3}{*}{$\begin{array}{l}\frac{5}{\tilde{u}} \\
\stackrel{u}{u} \\
\stackrel{u}{u}\end{array}$} & \multirow{2}{*}{ 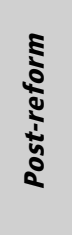 } & 융ํํ유 & 岗 & $\begin{array}{l}\dot{\theta} \\
\dot{d}\end{array}$ & 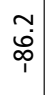 & $\hat{r}$ & 0 & $\hat{\dot{\omega}}$ & 웅 & m̊. & $\stackrel{\sim}{\underset{N}{N}}$ & $\stackrel{m}{m}$ & 0 & 웃 & 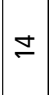 & $\stackrel{m}{\stackrel{m}{\sim}}$ & $\begin{array}{l}\underset{\infty}{0} \\
\stackrel{\sim}{\sim}\end{array}$ & $\underset{m}{m} \underset{p}{m}$ & $\frac{0}{\dot{m}}$ \\
\hline & & 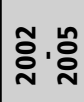 & $\begin{array}{l}\dot{0} \\
\dot{p}\end{array}$ & $\stackrel{\sim}{\beth}$ & $\mid \begin{array}{c}m \\
\tilde{m} \\
\dot{m} \\
m\end{array}$ & 导 & 은 & ஓ & $\begin{array}{c}0 \\
\infty \\
\infty \\
1 \\
1\end{array}$ & $\hat{\varphi}$ & $\mid \begin{array}{l}\bar{\infty} \\
\stackrel{\infty}{\infty} \\
i\end{array}$ & $\begin{array}{l}\infty \\
\dot{0} \\
\stackrel{p}{1}\end{array}$ & 0 & ¿্ণ & $\stackrel{2}{-}$ & வ & 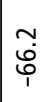 & 우 & ঙ্ষে \\
\hline & ఏ & 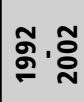 & 으 & $\stackrel{\text { L }}{\llcorner}$ & P & $\begin{array}{l}0 \\
\ddot{p} \\
\tilde{1}\end{array}$ & 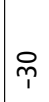 & 0 & 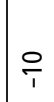 & $\stackrel{\sim}{\sim}$ & 离 & $\underset{\tau}{\stackrel{T}{\tau}}$ & レ & $\begin{array}{l}0 \\
\infty \\
1\end{array}$ & $\begin{array}{l}\stackrel{0}{0} \\
\stackrel{1}{1}\end{array}$ & $\stackrel{\nabla}{i}$ & $\frac{\pi}{6}$ & P & P \\
\hline \multirow{3}{*}{ 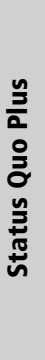 } & \multirow{2}{*}{$\begin{array}{l}\Xi \\
\vdots \\
\vdots \\
\vdots \\
\vdots \\
\vdots\end{array}$} & 올 '율 & $\underset{T}{\mathbb{N}}$ & $\underset{i}{\stackrel{i}{i}}$ & กี & $\begin{array}{l}m \\
\stackrel{p}{p} \\
\grave{1}\end{array}$ & $\underset{\uparrow}{\sim}$ & $\bar{\varphi}_{1}$ & $\stackrel{\sim}{\underset{T}{r}}$ & $\frac{n}{\underset{\gamma}{f}}$ & $\underset{\sim}{\stackrel{\sim}{\sim}}$ & 足 & 守 & 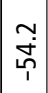 & $\underset{1}{9}$ & $\frac{n}{1}$ & o్ & ָี & ণ̊ \\
\hline & & 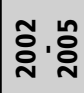 & $\begin{array}{l}\stackrel{L}{\infty} \\
\stackrel{\infty}{T}\end{array}$ & $\bar{\tau}$ & $\mid$\begin{tabular}{l|}
$\infty$ \\
$\dot{f}$ \\
$\dot{+}$ \\
1
\end{tabular} & 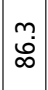 & $\grave{I}$ & $\frac{\widehat{O}}{1}$ & $\bar{g}$ & \begin{tabular}{|l|}
$\stackrel{n}{n}$ \\
$\stackrel{n}{r}$ \\
$T$
\end{tabular} & 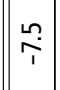 & $\stackrel{2}{n}$ & - & $\hat{\grave{d}}$ & $\begin{array}{l}\stackrel{m}{ \pm} \\
\dot{\sim}\end{array}$ & $\stackrel{\nabla}{\sim}$ & g̊ & $\begin{array}{l}0 \\
0 \\
1\end{array}$ & $\underset{1}{\stackrel{n}{r}}$ \\
\hline & ఏ & รั.ర్ ธิ & $\stackrel{+}{\stackrel{\sim}{\sim}}$ & $\stackrel{m}{n}$ & \begin{tabular}{|l|}
$\stackrel{n}{\tilde{\theta}}$ \\
$\tilde{\theta}$
\end{tabular} & $\begin{array}{l}m \\
\dot{0} \\
m \\
1\end{array}$ & $\begin{array}{l}+ \\
\infty \\
\infty \\
i \\
1\end{array}$ & ฉั & $\stackrel{\infty}{\sim}$ & \begin{tabular}{|l}
$\stackrel{n}{n}$ \\
$\stackrel{m}{n}$
\end{tabular} & $\mid \begin{array}{c}m \\
\stackrel{\infty}{\infty}\end{array}$ & 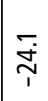 & 웅 & $\mid \begin{array}{l}n \\
\dot{1} \\
1\end{array}$ & $\frac{n}{6}$ & $\bar{d}$ & in & \begin{tabular}{|l} 
Ln \\
மn
\end{tabular} & 누 \\
\hline \multirow{3}{*}{ 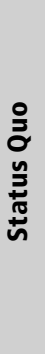 } & \multirow{2}{*}{ 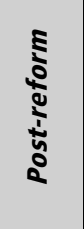 } & 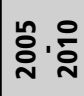 & $\frac{\bar{n}}{\frac{n}{1}}$ & $\frac{m}{\dot{m}}$ & خे. & 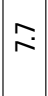 & 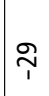 & 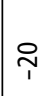 & $\begin{array}{l}\infty \\
\dot{Y} \\
\text { I }\end{array}$ & $\underset{\sim}{\stackrel{T}{T}}$ & $\mid \begin{array}{l}\infty \\
\dot{f} \\
\text { f }\end{array}$ & $\begin{array}{l}\infty \\
0 \\
0 \\
1\end{array}$ & $\underset{\tau}{\sim}$ & $\begin{array}{c}\sim \\
0 \\
1 \\
1\end{array}$ & $\stackrel{\stackrel{?}{=}}{=}$ & 㝘 & $\begin{array}{l}\infty \\
\dot{p} \\
\dot{p}\end{array}$ & $\begin{array}{l}\stackrel{n}{n} \\
\stackrel{n}{1}\end{array}$ & ำ \\
\hline & & 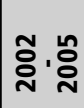 & $\stackrel{m}{\sim}$ & 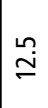 & $\hat{\dot{m}}$ & 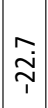 & O̊. & & $\begin{array}{l}\stackrel{n}{n} \\
\stackrel{n}{m}\end{array}$ & 吕 & $\mid \begin{array}{l}\stackrel{\varphi}{m} \\
\ddot{m}\end{array}$ & 官 & $\begin{array}{l}n \\
\varphi \\
\varphi\end{array}$ & $\begin{array}{l}m \\
\stackrel{m}{n} \\
\stackrel{n}{n}\end{array}$ & 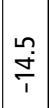 & $\begin{array}{l}0 \\
\stackrel{0}{+} \\
1\end{array}$ & $\approx$ & $\begin{array}{l}\infty \\
\infty \\
1\end{array}$ & $\stackrel{\sim}{\stackrel{n}{m}}$ \\
\hline & ذِ & ภั.ర్ & $\begin{array}{l}\infty \\
\stackrel{\infty}{\varphi}\end{array}$ & $\stackrel{\Delta}{\grave{\sim}}$ & $\mid \begin{array}{l}\stackrel{\llcorner}{0} \\
\infty \\
\infty\end{array}$ & 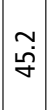 & 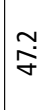 & 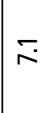 & $\begin{array}{c}m \\
\infty \\
m\end{array}$ & 今े & 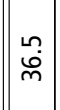 & 岗 & 六 & $\stackrel{\infty}{\stackrel{\sim}{\beth}}$ & $\underset{T}{\check{T}}$ & $\begin{array}{l}\infty \\
\stackrel{\Upsilon}{0} \\
i\end{array}$ & $\hat{\sigma}$ & $\frac{\tilde{J}}{\tilde{J}}$ & ণ্ \\
\hline \multirow{3}{*}{ 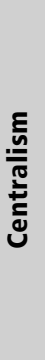 } & \multirow{2}{*}{ 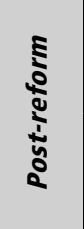 } & 눙ํํ & $\bar{m}$ & 苞 & $\begin{array}{c}m \\
o \\
0\end{array}$ & 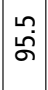 & $\begin{array}{l}\stackrel{n}{0} \\
\infty \\
0\end{array}$ & 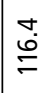 & బู่ & 뭉 & $\mid \begin{array}{l}\sim \\
\dot{0} \\
\infty\end{array}$ & $\stackrel{\mathscr{Z}}{\mathfrak{Y}}$ & $\begin{array}{l}\infty \\
\infty \\
\dot{\sigma}\end{array}$ & $\frac{\infty}{\sigma}$ & $\begin{array}{l}\infty \\
\stackrel{\infty}{m} \\
\stackrel{m}{n}\end{array}$ & $\stackrel{\bar{\tau}}{i}$ & $\stackrel{\circ}{m}$ & $\begin{array}{l}9 \\
\dot{9} \\
\dot{q}\end{array}$ & $\frac{\infty}{\dot{\gamma}}$ \\
\hline & & 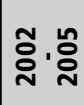 & $\stackrel{\circ}{-}$ & $\hat{\pi}$ & $\stackrel{\infty}{\stackrel{\infty}{\bar{T}}}$ & $\stackrel{\stackrel{n}{\sim}}{\stackrel{m}{m}}$ & 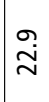 & $\frac{\infty}{1}$ & $\underset{i}{i}$ & oํ. & $\mid \underset{\sim}{\stackrel{m}{i}}$ & in & $\stackrel{\nabla}{\circ}$ & $\begin{array}{l}0 \\
1\end{array}$ & $\begin{array}{l}\infty \\
\dot{j} \\
\dot{p}\end{array}$ & $\overline{\dot{\sim}}$ & $\check{\Xi}$ & $\infty$ & $\frac{0}{\dot{p}}$ \\
\hline & ఏ & 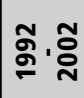 & ণ̃ & $\begin{array}{l}\infty \\
\infty \\
\infty \\
\Gamma \\
\Gamma\end{array}$ & $\stackrel{m}{m}$ & 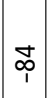 & $\frac{\dot{\sigma}}{\dot{p}}$ & ڤ̆ & $\begin{array}{l}0 \\
\stackrel{T}{r}\end{array}$ & $\stackrel{m}{\underline{n}}$ & $\mid \stackrel{\infty}{\stackrel{\infty}{\sim}}$ & $\underset{i}{\sim}$ & $\stackrel{\sim}{n}$ & 年 & $\underset{\sim}{\stackrel{m}{\tau}}$ & $\begin{array}{l}m \\
0 \\
0 \\
\varphi\end{array}$ & $\stackrel{\sim}{i}$ & $\bar{\gamma}$ & 웅 \\
\hline & & & $\begin{array}{l}\frac{\pi}{\sqrt{9}} \\
\frac{\sqrt{\frac{\pi}{0}}}{\frac{\pi}{0}} \\
\frac{\mathrm{c}}{4}\end{array}$ & 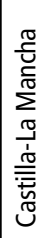 & 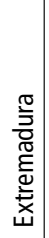 & $\begin{array}{l}\frac{0}{2} \\
\stackrel{0}{0} \\
\frac{0}{2} \\
2\end{array}$ & $\mid \begin{array}{l}\frac{\pi}{0} \\
\frac{0}{2} \\
0 \\
3\end{array}$ & 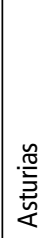 & 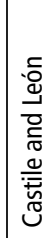 & 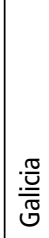 & 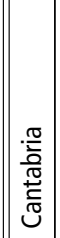 & $\begin{array}{l}: \frac{0}{2} \\
\frac{0}{0} \\
\Sigma\end{array}$ & 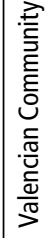 & 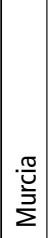 & 离 & 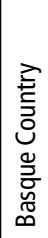 & 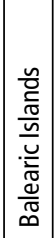 & 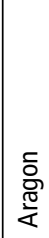 & 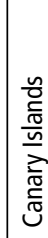 \\
\hline
\end{tabular}




\section{ABSTRACT}

This article explores the changes that have taken place in public opinion preferences with respect to the model of political organisation in Spain following the last wave of statutory reforms. The article is based on data collected from surveys carried out by the Centre for Sociological Research between 2002 and 2010 and aims primarily to detecting the extent to which the preference for a model of decentralisation, such as that which currently exists (and which is referred to as the "status quo" throughout the article) has undergone major changes during the period of analysis, and in which autonomous communities. The article concludes that simultaneous to the statutory reforms there have been major changes in public perception of the "institutional goodwill" that exists in the current institutional model of decentralisation and self-government. Specifically, while some communities under the current model have begun to question why it cannot adapt to some of the more ambitious expectations of self-government, in other communities the present model has been questioned precisely for the opposite reason: to understand why the current model of political decentralisation has gone too far. So for the first time in some of the autonomous communities the preference for self-government involution (i.e., preference for centralism and cuts in self-government powers) is greater than that expressed in the current decentralisation model.

Key words: statutory reforms; model of regional organisation; public opinion; Centre for Sociological Research; self-government.

\section{RESUM}

Aquest article explora els canvis que s'han produït en les preferències dels ciutadans respecte del model d'organització territorial de l'Estat espanyol d'ençà de la darrera onada de reformes estatutàries. Fonamentat en dades d'enquestes dutes a terme pel Centre d'Investigacions Sociològiques entre 2002 i 2010, l'article se centra a detectar fins a quin punt i en quines comunitats autònomes la preferència per un model de descentralització com l'actual (el que s'anomena statu quo a l'article) ha sofert canvis al llarg del període. L'article conclou que simultàniament a les reformes estatutàries, hi ha hagut canvis importants en la percepció que tenen els ciutadans respecte de la "bondat institucional" de l'actual model de descentralització autonòmica. En concret, mentre en algunes comunitats autònomes el model actual $s$ 'ha començat a qüestionar per entendre's que no permet acomodar unes 
expectatives més ambicioses d'autogovern, en d'altres comunitats el model actual s'ha qüestionat just pel contrari: per entendre's que el model de descentralització ha anat massa lluny. Així, en algunes comunitats i per primer cop, les preferències envers una involució autonòmica (centralisme i retallada de competències autonòmiques) superen les adreçades al model actual de descentralització.

Paraules clau: reformes estatutàries; model d'organització territorial; opinió pública; Centre d'Investigacions Sociològiques; autogovern.

\section{RESUMEN}

El artículo explora los cambios que se han producido en las preferencias de los ciudadanos respecto el modelo de organización territorial del estado español a partir de la última ola de reformas estatutarias. El artículo se fundamenta en datos de encuestas realizadas por el Centro de Investigaciones Sociológicas entre 2002 y 2010 y está centrado en detectar hasta qué punto y en qué comunidades autónomas, la preferencia por un modelo de descentralización como el actual (lo que a lo largo del artículo se denomina "statu quo") ha sufrido cambios importantes durante el período de análisis. El artículo concluye que simultáneamente a las reformas estatutarias se han producido cambios importantes en la percepción que los ciudadanos tienen de la "bondad institucional" del actual modelo de descentralización autonómica. En concreto, mientras que en algunas comunidades el actual modelo se ha empezado a cuestionar por entender que no permite acomodar unas expectativas más ambiciosas de autogobierno, en otras comunidades el modelo actual se ha cuestionado precisamente por lo contrario: por entenderse que el modelo actual de descentralización política ha ido demasiado lejos. Así, por primera vez en algunas comunidades las preferencias hacia una involución autonómica (centralismo y recorte de las competencias autonómicas) superan a las del actual modelo de descentralización.

Palabras clave: reformas estatutarias; modelo de organización territorial; opinión pública; Centro de Investigaciones Sociológicas; autogobierno. 